\title{
Sustainable management of hill land
}

A.D. MACKAY', M.E. WEDDERBURN ${ }^{2}$ and M.G. LAMBERT ${ }^{1}$

${ }^{\prime}$ AgResearch, Grasslands Research Centre, Private Bag 11008, Palmerston North

${ }^{2}$ AgResearch, Whatawhata Research Centre, Private Bag 3089, Hamilton

\section{Abstract}

One of the major environmental issues currently facing New Zealand is that of the sustainability of pastoral farming on North Island hill country. To be sustainable, a system must be resource conserving, environmentally compatible, socially supportive and commer-cially competitive. The Resource Management Act defines sustainable management as managing the use, development and protection of natural and physical resources in a way, or at a rate, which enables people and community to meet their needs without unduly compromising the ability of future generations to meet their needs. Evidence shows that at present this is not so for some hill country, for reasons of on-site land degradation and soil loss, and off-site sediment loading. Socioeconomic sustainability is also in doubt through deterioration in rural infrastructure and social services and steadily decreasing average returns for produce. In the long term there is no conflict between environmental and economic sustainability. The major conflict arises in the short term when the environmental needs of the community can conflict severely with the economic survival of the individual land holder. Adoption of sustainable management will require a much greater understanding of the dynamic interaction between land resources and land use practices and improved matching of land uses with inherent soil and climatic properties. A quantitative understanding of the relationship between biophysical stability of our land resources and their productive capability is required. This paper attempts to: (i) examine how biophysical indicators could be used to quantify the impact of current land use on the productive capability of our hill land resource, and in so doing identify several critical issues facing hill country farmers, and (ii) discuss some of the possible solutions to what we see are currently unsustainable farming practices. It is our contention that the adoption of sustainable management practices will ensure the long-term viability of this sector of the pasture industry and not, as many suggest, its demise.
K eywords: biophysical indicators, hill land, offsite effects, on-site effects, sustainability

\section{Introduction}

One of the major environmental issues facing New Zealand is that of the sustainability of pastoral farming on North Island hill country. To be sustainable, a system must be resource conserving, environmentally compatible, socially supportive and commercially competitive (Rodale 1983). The Resource Management Act (RMA) defines sustainable management as managing the use, development and protection of natural and physical resources in a way, or at a rate, which enables people to meet their needs without unduly compromising the ability of future generations to meet their own needs. There is evidence to show that at present this is not the case for some hill country, for reasons of on-site land degradation and soil loss, and off-site sediment loading (Blaschke et al. 1992). Socioeconomic sustainability is also in doubt through deterioration in rural infrastructure and social services and steadily decreasing average returns for produce (New Zealand MWBES 1993). Disposable profits are low, despite tight budget control.

Improving the long-term profitability and hence economic and social sustainability of hill farming systems will be achieved only if the systems are in the long term biophysically sustainable, because systems that fail to conserve their resource base will eventually lose their ability to produce. However, major conflicts can arise in the short term, between individual producers and society. This is because short-term profitable systems may not be ecologically sustainable, and shortterm sustainable systems may not be profitable for individual farmers (Ikerd 1990).

Although most New Zealand landholders probably have a strong stewardship ethic, and would like to manage their land resources sustainably, financial pressures and a lack of knowledge of the required management practices are often preventing this from happening. Sustainable management will require a much greater understanding of the dynamic interaction between land resources and land use practices, and improved matching of land uses with inherent soil and climatic properties (Glasby 1991). To achieve this objective a quantitative understanding of the relationship 
between biophysical stability of our land resources and their productive capability is required. The intention of this paper is to:

(a) examine how biophysical indicators could be used to describe the state of our hill land resource and quantify the impact of agricultural practices on the productive capability of our hill land;

(b) identify several critical issues facing hill country farmers; and

(c) discuss some of the possible solutions to what we see as currently unsustainable farming practices.

We feel that the adoption of more sustainable land management practices by hill farmers will increase the long-term viability of hill farming, when used in conjunction with increased awareness of landholders to not only the limitations but also the productive capability of the various land units that makes up their properties. The decision ultimately on what is sustainable or acceptable will be made in conjunction with the provisions of the RMA. Deciding on an acceptable pathway for defining and meeting that goal will require a partnership between landowners, policy makers and community, as the RMA embraces social in addition to biological and economic goal. In essence it is an issue which we have to solve ourselves. Just as the problem is home-grown, so must be the solutions.

\section{North Island hill land}

North Island hill land covers 3.5 million ha (28\% of farmland in New Zealand). Over the last decade sheep and beef stock numbers have declined (13\%) steadily, resulting primarily from a $45 \%$ reduction in fertiliser use from the peak in the late 1970s and early 1980s. At present this land resource carries $35 \%$ of total sheep (19 million) and $20 \%$ of total cattle numbers and is farmed in 6800 farm holdings representing $30 \%$ of New Zealand sheep and beef farms.

Hill land constitutes a dynamic environment undergoing long-term geomorphological changes governed by tectonics, rock type, vegetation, climate and, in the last 150 years, pastoral farming enterprises. The conversion of forested hill country to pasture was generally without regard to the physical limitations of slope stability, soil fertility or vegetative cover (Eyles \& Newsome 1992). Superimposed on this recently modified landscape is an extremely variable climate with high intensity rainstorm, drought, severe frost and high wind velocities.

The result has been extensive and often severe onsite accelerated soil erosion and off-site flooding and sediment loading. These are the highly visual impacts of current hill country pastoral use and the focus of most of the current debate on the sustainability of hill land. We would like to extend the usual discussion of accelerated soil erosion and its control, to a consideration of other less dramatic effects of our farming practices, which also threaten the long-term stability and productive capability of this resource.

\section{Biophysical factors for quantifying the impact of agricultural practices on hill land}

The biophysical indicators that describe and can be used to quantify the impact of land use on our hill land resource can be divided into two broad groups (Table 1). Those that describe and measure:

(a) On-site effects: including accelerated and insidious soil loss, soil structural decline, nutrient depletion and losses, contaminants, vegetation degradation and weed infestation,

(b) Off-site impacts: including water quality and eutrophication, sediment loading.

The list of biophysical indicators in Table $\mathbf{1}$ is not exhaustive. Below we examine a few from the list, to highlight how they can be used to examine the impact of current land use. Preservation of indigenous vegetation and habitat is listed as a biophysical indicator, to highlight the diversity of goals that must be met in developing a sustainable management plan that attempts to satisfy all interested parties. Off-site impacts are not discussed separately here but are treated as an indicator of on-site influences.

\section{(a) Soil loss}

\section{(i) Accelerated soil loss:}

The impact of earth slumping and massive movement since deforestation on the productive capability of hill land, and on the wider environment, is well documented and visible to all New Zealanders. Trustrum et al. (1990) has shown that on hill slopes $>42^{\circ}$ soil losses exceed soil formation. This implies that pasture production is not sustainable. On these slopes, slip scars may never achieve more than $70-85 \%$ of the productive potential that it had when forest was initially removed (Lambert etal. 1984). On slopes of $28-42^{\circ}$, Trustrum et al. (1990) suggested that soil loss limits pasture growth and still contributes to sediment loading, but on slopes $<28^{\circ}$ land is capable of sustaining pasture production.

Broad landscape units in hill country with slopes of 42 " can be readily identified from the LUC (land use capability) worksheets, which form part of the New Zealand Land Resource Inventory, and protected 
Table 1 On-site and off-site factors in sustanable land use.

\begin{tabular}{|c|c|c|c|}
\hline & Issue & Detrimental Practices & Ameliorating Practices \\
\hline \multicolumn{4}{|c|}{ - On-site } \\
\hline & 1 Accelerated soil loss & - Poor matching of enterprise to capability of land. & $\begin{array}{l}\text { - Improved land capability assessment } \\
\text { - Afforestation. } \\
\text { - Conservation planting. }\end{array}$ \\
\hline & 2 Insidious & $\begin{array}{l}\text { - Inappropriate grazing regime. } \\
\text { - Insufficient vegetation cover. } \\
\text { - Inappropriate vegetation types. }\end{array}$ & $\begin{array}{l}\text { - Block vs strip grazing. } \\
\text { - Minimum pasture covers. } \\
\text { - Tree/pasture associations. } \\
\text { - Riparian strips. }\end{array}$ \\
\hline & Soil structural decline & $\begin{array}{l}\text { - Animal treading. } \\
\text { - Inadequate pasture cover. } \\
\text { - Inappropriate stock type/grazing regime, }\end{array}$ & $\begin{array}{l}\text { - Matching stock type to soil type/conditions. } \\
\text { - Minimum pasture covers. } \\
\text { - Block vs strip grazing. }\end{array}$ \\
\hline 3 & $\begin{array}{l}\text { Nutrient depletion, } \\
\text { imbalance, acidification }\end{array}$ & $\begin{array}{l}\text { - Insufficient/inappropriate fertiliser use. } \\
\text { - Excessive fertiliser use. } \\
\text { - Over stocking. }\end{array}$ & $\begin{array}{l}\text { - Maintenance fertiliser inputs. } \\
\text { - Matching of carrying capacity. } \\
\text { - Balance nutrient inputs. }\end{array}$ \\
\hline 4 & Biological activity & $\begin{array}{l}\text { - Animal treading, overgrazing. } \\
\text { - Inadequate pasture cover. } \\
\text { - Excessive chemical use. }\end{array}$ & $\begin{array}{l}\text { - Better matching of stock type to soil type/conditions } \\
\text { - Minimum pasture covers. } \\
\text { - Biocontrols. }\end{array}$ \\
\hline 5 & Contaminants/Residues & $\begin{array}{l}\text { - Over reliance on chemical control of weeds. } \\
\text { - Heavy metal contamination (eg. Cd). } \\
\text { - Over use of pesticides. }\end{array}$ & $\begin{array}{l}\text { - Biocontrols. } \\
\text { - Fertiliser sources low in heavy metals. } \\
\text { - Selection for resistance. } \\
\text { - Whole farm integrated weed management. }\end{array}$ \\
\hline 6 & $\begin{array}{l}\text { Vegetation degradation/ } \\
\text { weed infestation }\end{array}$ & $\begin{array}{l}\text { - Poor grazing management. } \\
\text { - Over grazing. } \\
\text { - Inappropriate stock classes/grazing regime. } \\
\text { - Insufficient fertiliser use. }\end{array}$ & $\begin{array}{l}\text { - Improved grazing management } \\
\text { - Subdiiision. } \\
\text { - Integrated grazing regimes. } \\
\text { - Selective herbicide use. } \\
\text { - Maintenance of fertiliser inputs. } \\
\text { - Biocontrols. }\end{array}$ \\
\hline 7 & Pest infestation & $\begin{array}{l}\text { - Grazing management } \\
\text { - Inappropriate stock types. } \\
\text { - Poor targeting. }\end{array}$ & $\begin{array}{l}\text { - Biocontrols. } \\
\text { - Integrated pest management. }\end{array}$ \\
\hline 8 & $\begin{array}{l}\text { Loss of indigenous } \\
\text { vegetation and habitats }\end{array}$ & $\begin{array}{l}\text { - Overgrazing. } \\
\text { - Inappropriate stock types. }\end{array}$ & - Retirement/protection. \\
\hline \multicolumn{4}{|c|}{ - Off-sile } \\
\hline & $\begin{array}{l}\text { Water quality/ } \\
\text { Eutrophication }\end{array}$ & $\begin{array}{l}\text { - Inappropriate land use. } \\
\text { - Inadequate waste/effluent disposal. } \\
\text { - Contamination of surface and ground water. } \\
\text { - Excessive/inappropriate fertiliser use. }\end{array}$ & $\begin{array}{l}\text { - Improved land capability assessment. } \\
\text { - Management (grazing, stock type, tree planting etc) } \\
\text { to minimise soil erosion. } \\
\text { - Modify fertiliser application strategies/types. } \\
\text { - Care in pesticide/herbicide use. } \\
\text { - Riparian strips. }\end{array}$ \\
\hline 10 & Sedimentation & $\begin{array}{l}\text { - Inappropriate land use. } \\
\text { - Inappropriategrazing regime/vegetative cover. }\end{array}$ & $\begin{array}{l}\text { - Improved landcapability assessment } \\
\text { - Minimum pasture covers. } \\
\text { - Riparian strips. }\end{array}$ \\
\hline 11 & Water yields & $\begin{array}{l}\text { - Inappropriate land use. } \\
\text { - Insufficient pasture cover. }\end{array}$ & $\begin{array}{l}\text { - Water harvesting. } \\
\text { - Minimum pasture covers. }\end{array}$ \\
\hline 12 & Waste/effluent disposal & - Point source discharges of waste/ effluent. & - Improved engineering for effluent disposal. \\
\hline
\end{tabular}

by soil conservation tree planting or afforestation. Attempts to pastoral farm these landscape units, which often have extreme seasonal variation in pasture growth and consequently poor utilisation by livestock, are not sustainable. The technology exists for identifying and mapping these landscapes on a paddock basis. Matching farm enterprises with land capability to reduce the pressure on this component of the landscape is a positive step in the right direction. Hill country properties that have initiated a long-term programme to retire and plant in trees eroding class VII and protect with conservation trees susceptible class VI land, have in the same exercise identified the most productive and valuable parts of the farm. Allocating inputs to the more versatile land units could lift overall farm profitability. 
It is often difficult, however, to separate out the suspectible landscape unit into discrete parcels, because it tends to constitute a discontinuous component of landscape. This necessitates the need to also remove land units that are less susceptible to erosion and of greater productive capability. Techniques for introducing conservation and timber-producing trees other than Pinus radiata into these situations still requires more study.

\section{(ii) Insidious soil loss}

Insidious topsoil loss is not necessarily a source of large quantities of sediment from catchments; however, the loss of topsoil and associated nutrients degrades and has a significant off-site impact on sediment loading in rivers and water quality. In one of the few studies in hill country, Lambert et al. (1985) measured soil losses of 2.7 tonnes/ha from hill land $\left(21^{\circ}\right)$ under intensive cattle management. Associated with this loss of topsoil was an annual loss of $12 \mathrm{~kg} \mathrm{~N}$ and $1.5 \mathrm{~kg} \mathbf{P} / \mathrm{ha}$. This loss of topsoil and nutrient reduces the potential productive capability of the hill land. In a similar catchment under sheep grazing, soil and nutrient losses per ha were only 1.1 tonnes, and $8 \mathrm{~kg} \mathrm{~N}$ and $0.7 \mathrm{~kg} \mathrm{P}$, respectively.

In addition to the impact of stock type, other practices that are likely to cause the surface loss of soil and sediment include: the poor matching of stock type with land slope; overgrazing; lack of pasture cover; treading damage on slopes and also damage to water courses and stream banks. To date the number of studies that have examined the impact of agricultural practices on these soil loss are limited, as is our understanding of the long-term effects of the loss of topsoil on the productive capability of the resource. It is not unreasonable to assume that soil loss represents at best a loss of 'potential capability'.

One action pastoral farmers can take to reduce insidious soil losses is to introduce soil conservation objectives into their grazing management plan. Practices that could be incorporated to reduce soil and nutrient loss include: a better matching of stock type and land capability; using block rather than strip grazing; leaving sufficient pasture covers after grazing to provide a canopy to protect the soil surface and to act as a sediment trap; and the use of riparian strips around water courses to trap sediment. While these practices may not increase production, they may assist in retaining the long-term productive capability of the resource by retaining soil and nutrients and reducing losses into waterways. Unfortunately there is little evidence available as to exactly which practices are most damaging, and which are most resource conserving. The above examples serve to give some indication of the additional management that may be required to meet the multiple objectives of utilising pasture in a sustainable way. Maximising the utilisation of grown pasture will no longer be the sole objective of the grazing management plan.

\section{(b) Soil structural decline}

Edmond (19.58) found that as the intensity of stock treading of Romney ewes increased from 0 to $20 \mathrm{su} / \mathrm{ha}$, pasture regrowth during late winter and spring was almost halved. The decline in pasture growth was brought about by damage to pasture plants and physical damage to the soil.

In addition to treading damage, other factors likely to contribute to a decline in soil structure and physical health include; the poor matching of stock type and land capability; inappropriate grazing regime; inadequate pasture cover; and the loss of biological activity. A decline in soil structure will in turn affect drainage; soil oxygen supply; bulk density and soil compaction (Greenwood \& McNamara 1992); soil moisture holding capacity; and plant rooting depth and tiller density (Edmond 1958), all of which affect pasture supply. The impact stock treading has on hill slopes $\left(>15^{\circ}\right)$ has not been investigated.

Preserving or preventing physical damage to soils adds another objective into the package for managing the land resource in a sustainable way. To achieve this a measure of the physical condition of soils will need to be added to the list of biophysical information (e.g., pasture covers, soil fertility) routinely measured on farms. There is evidence from the cropping scene (Shepherd 1991) to show that as soil structure declines, the quantities of inputs required to maintain a productive capability must be increased. In the long term there may be some good financial reasons for monitoring soil physical characteristics with the objective of holding the structural characteristics of the soil within a given set of limits.

\section{(c) Nutrient depletion and imbalances}

Of the biophysical factors listed in Table 1, nutrient supply is one that affect dramatically the short- and medium-term productive capability of hill lands (Clark et al. 1990) and one that can be readily manipulated by the land user. There is evidence for nutrient depletion (Lambert et al. 1990), nutrient imbalances (Carran 1992), and nutrient and base cation losses (Sakadevan et al. 1993) due to inadequate or inappropriate fertiliser use, or as a result of exploitative grazing practices, occurring in agricultural soils. The affect these changes will have on the long-term productive capability of our soils resources is not clear. By gaining a better understanding of nutrient cycling and losses in hill 
soils a more comprehensive approach to the maintenance of nutrient contents could be developed.

\section{(d) Vegetation degradation and weed infestation} The climax plant community in much of our hill land, particularly wet areas, was rain forest. Hill pastures will return to forest if not repeatedly fertilised and grazed. The progressive loss of desirable and productive forage plants, as a consequence of inadequate/ inappropriate subdivision, grazing management, or fertiliser inputs and the slow invasion of wood weeds (reversion) as a result of reducing grazing pressure and competition from herbaceous plants, provides land managers with a good indicator of the decline in the productive capability of a landscape. Conversely, weed infestation, brought about by excessive grazing or treading damage, may also provide a useful tool for gauging the changes in the stability of the resource.

\section{Monitoring of biophysical indicators}

An effective on-site programme for monitoring change in the status of biophysical indicators should eliminate the need for extensive off-site monitoring of the environment, as many of the practices that are likely to have an effect off-site can be assessed on-site. Data on a significant number of these parameters could be collected by the landowner in tandem with the physical information (pasture covers, soil fertility, soil temperatures, available soil moisture) routinely collected on some properties for the purpose of evaluating current and planning future farm activity. At present, however, our understanding of the quantitative relationship between the biophysical factors required to describe pastoral systems and productive capability is limited and it is currently the subject of intense research

\section{Conclusion}

Sustainable management will require a much greater understanding of the dynamic interaction between the land resources and land use practices and an improved matching of land use with inherent soil and climatic properties. This will require landowners to have a better understanding of behaviour of their biophysical resources. It will increase the complexity of on-farm decision making, by adding resource management objectives to the farm plan. Far from threatening the viability of traditional hill country farming systems, incorporating resource management as an integral part of the farm management plan will ensure the long-term viability of this sector of the pastoral industry.

\section{REFERENCES}

Blaschke, P.M.; Trustrum, N.A.; De Rose, R.C. 1992. Ecosystem processes and sustainable land use in New Zealand steeplands. Agriculture, ecosystems and environment 4: 153- 178.

Carran, R.A. 1992. Managing soil acidity: old solutions can cause new problems. Proceedings of the New Zealand Grassland Association 54:77-80.

Clark, D.A.; Ledgard, S.F.; Lambert, M.G. 1990. Longterm effects of withholding phosphate application on North Island hill country: Economics. Proceedings of the New Zealand Grassland Association 51: 29-34.

Edmond, D.B. 1958. The influence of treading on pasture. A preliminary study. New Zealand journal of agricultural research I: 319-328.

Eyles, G.O.; Newsome, P.F. 1991. A soil-conservation approach to sustainable land use. Proceedings of the International Conference on Sustainable Lund Management. Napier, Hawkes Bay, New Zealand. Ed. P. Henriquies. Pp. 216-220.

Glasby, G.P. 1991. A review of the concept of sustainable management as applied to New Zealand. Journal of the Royal Society of New Zealand 21: 61-81.

Greenwood, P.B.; McNamara, R.M. 1992. An analysis of the physical condition of two intensively grazed Southland soils. Proceedings of the New Zealand Grassland Association 54: 7 1-75.

Ikerd, J.E. 1990. Agriculture's search for sustainability and profitability. Journal of soil and water conservation 45: 18-23.

Lambert, M.G.; Trustrum, N.A.; Costall, D.A. 1984. Effect of slip erosion on seasonally dry Wairarapa hill pastures. New Zealand journal of agricultural research 27: 57-64.

Lambert, M.G.; Devantier, B.P.; Nes, P.; Penny, P.E. 1985. Losses of nitrogen, phosphorus, and sediment in runoff from hill country under different fertiliser and grazing management regimes. New Zealand journal of agricultural research 28: 371-379.

Lambert, M.G.; Clark, D.A.;Mackay, A.D. 1990. Long term effects of withholding phosphate application on North Island hill country: Ballantrae. Proceedings of the New Zealand Grassland Association 51: 25 28.

New Zealand Meat and Wool Boards Economic Service 1993. A review of financial and production trends in the New Zealand Sheep and Beef Sector. Paper No. G2054. March 1993.

Rodale, R. 1983. Breaking new ground: the search for sustainable agriculture. Futurist 17: 15-20. 
Sakadevan, K.; Hedley, M.J.; Mackay, A.D. 1993. Influence of sheep excreta on pasture uptake and leaching losses of sulphur, nitrogen and potassium from grazed pasture. Australian journal of soil research 31: 151-162.

Shepherd, T.G. 199 1. Sustainable soil-crop management and its economic implications for grain growers. Proceedings of the International Conference on Sustainable Land Management. Napier, Hawkes Bay; New Zealand. Ed. P. Henriques. Pp. 141-152.

Trustrum, N.A.; Blaschke, P.M.; De Rose, R.C.; West, A. 1990. Reolith changes and pastoral productivity declines following deforestation in steeplands of North Island New Zealand. Transcripts of the 14th International Congress Soil Science, Kyoto, Japan 1: 125-130. 